\title{
Influence of lactose intolerance on colorectal cancer incidence in the Polish population
}

\author{
Plawski Andrzej ${ }^{1 *}$, Machtel Piotr², Pawel Borun', Marzena Skrzypczak-Zielinska', Arleta Wojciechowska-Lacka ${ }^{3}$, \\ Dariusz Godlewski ${ }^{4}$, Tomasz Banasiewicz ${ }^{4}$
}

From Annual Conference on Hereditary Cancers 2013

Szczecin, Poland. 26-27 September 2013

During the last few years, a lot of efforts have been devoted to determine potential risk factors of colorectal cancer (CRC). One such agent which might increase susceptibility to sporadic CRC is an ailment of digestive system called lactose intolerance, since it negatively effects functioning of the intestines (after lactose consumption). It is caused by acidification of the lumen, osmotic balance disturbance, and an alteration in intestinal bacteria composition. Primary lactose intolerance is a genetic disorder caused by several loci, from which the most important for the Caucasian population is $L C T-13910 \mathrm{~T}>\mathrm{C}(\mathrm{C} / \mathrm{C}$ - lactose intolerant phenotype, $\mathrm{C} / \mathrm{T}$ and $\mathrm{T} / \mathrm{T}$ - lactose persistent). It is located in intron 13 of the MCM6 gene and operates as an enhancer of the $L C T$ gene. The major aim of the following studies was to check a correlation between incidence of lactose intolerance and increased risk of sporadic CRC development. The studies rest on genotyping of $L C T-13910$ loci in a group of control and 279 cases of sporadic CRC and comparison of frequencies of particular genotypes between those groups. Genotyping was performed by means of high resolution melting (HRM) analysis as a credible and fast genotyping method. Next, the results were subjected to statistical analysis by $\chi^{2}$ test of independence. The test, concerning association between lactose intolerance and sporadic CRC, achieved statistical significance. This observation may indicate the role of lactose intolerance as a risk factor for CRC (about $8 \%$ higher frequency of $L C T-13910 \mathrm{C} / \mathrm{C}$ genotype among CRC patients).
Authors' details

${ }^{1}$ Institute of Human Genetics, Poznan, Poland. ${ }^{2}$ Adam Mickiewicz University Poznan, Poland. ${ }^{3}$ International Oncotherapy Center, Koszalin, Poland. ${ }^{4}$ Center of Cancer Prevention and Epidemiology, Poznan, Poland.

Published: 9 September 2015

doi:10.1186/1897-4287-13-S1-A7

Cite this article as: Andrzej et al:: Influence of lactose intolerance on colorectal cancer incidence in the Polish population. Hereditary Cancer in Clinical Practice 2015 13(Suppl 1):A7.

* Correspondence: andp@man.poznan.pl

${ }^{1}$ Institute of Human Genetics, Poznan, Poland

Full list of author information is available at the end of the article

Submit your next manuscript to BioMed Central and take full advantage of:

- Convenient online submission

- Thorough peer review

- No space constraints or color figure charges

- Immediate publication on acceptance

- Inclusion in PubMed, CAS, Scopus and Google Scholar

- Research which is freely available for redistribution
() Biomed Central 